\title{
Adana Çukurova İlçesinde Yaşayan Hane Halkının Atık İlaç Konusunda Bilgi, Tutum ve Davranışları
}

\author{
Knowledge, Attitudes and Behaviors of Households Living in Cukurova District in \\ Adana about Medical Waste
}

\author{
Duygu Ayabakan Çot ${ }^{1}$, Necdet Aytaç ${ }^{2}$, Muhsin Akbaba ${ }^{2}$ \\ ${ }^{1}$ Nizip İlçe Sağlık Müdürlüğü, Gaziantep \\ ${ }^{2}$ Çukurova Üniversitesi, Tip Fakültesi, Dahili Tip Bilimleri Bölümü, Halk Sağ l̆ğı Anabilim Dalı, Adana
}

\author{
Yazışma Adresi / Correspondence: \\ Duygu Ayabakan Çot \\ Nizip İlçe Sağlık Müdürlüğü, Gaziantep \\ T: +90538 0274401 E-mail: : duyguayabakan@hotmail.com \\ Geliş Tarihi / Received : 06.05.2019 Kabul Tarihi / Accepted : 25.07.2019 \\ Orcid : \\ Duygu Ayabakan Çot https://orcid.org/0000-0002-6443-1171 \\ Necdet Aytac https://orcid.org/0000-0002-2560-2783 \\ Muhsin Akbaba https://orcid.org/0000-0003-3028-6698
}
$\ddot{0} z$
Amaç Bu çalışma Adana Çukurova ilçesinde yaşayan hane halkının atık ilaç konusunda bilgi, tutum ve davranışlarını belirlemek amacıyla yapılmıştır ( Sakarya Tip Dergisi 2019, 9(3):398-405 )
Gereç ve Kesitsel tanımlayıcı olan araștırma 2019 yılı Subat-Mart aylarında 384 haneden birer kiși ile yüz yüze görüsülerek yapılmıștır. Haneler sistematik örnekleme yöntemi ile Yöntemler seçilmiștir. Anket sosyodemografik veriler ve atık ilaç depolanması ve bertarafı ile ilgili 18 sorudan oluşmaktadır. Veriler Statistical Package ort he Social Sciences (SPSS) sürüm 25 paket programına girilmiştir. $\mathrm{P}<0,05$ anlamlı kabul edilmiştir.

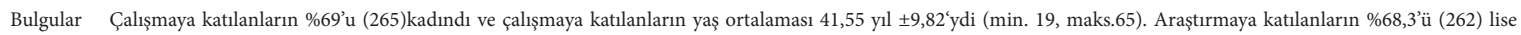 ve üstü bir okula gitmiști ve \%43,2'si (166) gelir getiren bir iște çalıșıyordu. Ailelerin \%30,5 (117) ’i 0-6 yaş aralığında küçük çocuğa sahipti. Evlerde kullanım dıșı kalmış ilaç sayısı ortalama 4,26/hane'ydi. Kullanım dıșı kalmaların en sık nedeni son kullanma tarihinin geçmiş olması ve hastanın ilacı beğenmeyerek kullanmaya devam etmek istememesi idi. İlaç çeșidi olarak ise sırayla en sık analjezik, antibiyotik ve antihistaminik ilaçlar gelmekteydi. İlaçların \%26,6’sı (102) uygunsuz yerlerde muhafaza edilmekteydi.
Sonuç Çalışmaya katılan evlerde atık ilaç sayısı çok yüksekti. Çalışmamızda evlerde bulunan atık yağ ve pillerini atık kutularına sürekli atan katılımcılar vardı fakat atık ilaçlarla ilgili herhangi bir uygulama olmaması bu kişilerin elini kolunu bağlamaktadır. Geri dönüșümü olmayan ilaçlar çocuk zehirlenmelerine de neden olmaktadır. Evlerde ki kullanım dışı kalmış ilaçların geri dönüşümü ile ilgili düzenlemeler ivedilikle yapılmalı ve başta gereksiz yazılmaması daha sonrasında ise geri dönüşümü sağlanmalıdır.
Anahtar Tibbi atık; Tibbi atık imhası; Zararlı atık
Kelimeler
Abstract
Objective This study was carried out to determine the knowledge, attitude and behaviors of households living in Adana Çukurova district about waste drug... ( Sakarya Med J 2019, 9(3):398-405).
Materials The cross-sectional descriptive study was conducted in February-March 2019 by one-to-one interviews with 384 households. Households were selected by systematic sampling method. The and Methods questionnaire consisted of 18 questions about sociodemographic data and waste drug storage and disposal. Data were entered in the Statistical Package for the Social Sciences ( SPSS) program. $P<0.05$ was considered significant.
Results $69 \%$ (265) of the participants were female and the mean age of the participants was 41.55 year \pm 9.82 (min. 19, max.65). Of the participants, 68.3\% (262) attended high school and higher edu- cation, and $43.2 \%$ (166) were employed in an income-generating job.30.5\% (117) of the families had small children aged 0-6. The average number of drugs out of house was 4.26 / household. The most common reason for the out-of-use was the expiration date and the patient's unwillingness to continue to use the drug. The most common medications were analgesics, antibiotics and antihistaminic drugs. $26.6 \%$ (102) of the drugs were kept in inappropriate places.
Conclusion The number of waste medication was very high in the participating households. In our study, there were participants who used to waste waste oil and batteries in the waste bins, but the lack of any application related to waste medication ties their hands. Drugs that are not recycled cause child poisoning. Regulations on the recycling of unused drugs should be done urgently and should not be written unnecessarily and then recycled.
Keywords Medical Waste; Medical Waste Disposal; Hazardous Waste




\section{GIIRIŞ}

Değişen dünyamızda özellikle gelişmiş ülkelerde zararlı atıklar en önemli çevre sorunlarından biri haline gelmiştir. Zararlı atıklar endüstri atıkları olarak düşünülse de yapılan araştırmalar depo yerlerine gelen katı atıkların \%1'ini zararlı atıkların oluşturduğunu ve bu zararlı atıkların \%20 'sinin de evsel kaynaklı olduğunu göstermiştir.' Evlerde kullanılan temizlik maddeleri, pestisitler, ilaçlar bu ürünlerden bazılarıdır ve evsel zararlı atık(EZA) adını alırlar. İstanbul metropolünde Evsel Zararlı Atıkların Araştırılması çalışmasında İstanbul'un çeşitli semtlerinden günlük atıklar temin edilmiş ve bu atıkların dağılımları belirlenmiştir. Bu atıkların içinde ilaç atıklarının en büyük payı kapladığı $(\% 41,6)$ tespit edilmiştir. ${ }^{2}$

Son kullanma tarihi geçmiş ilaçların etkin şekilde bertaraf edilmesinin koşullarının yaratılmadığı günümüzde bu ilaçlar akılcı olmayan ilaç kullanımı, çocuklarda ilaç zehirlenmeleri, intihar girişimleri, ilaç etkileşimleri gibi nedenlerle toplum sağlğ̆ını olumsuz şekilde etkilerken, bu ilaçların çöplere atılması ve lavabolara dökülmesi çevre sağlığını doğrudan etkilemektedir. Artık zehir niteliği kazanmış bu ilaçlar yeraltı kaynaklarını kirletmekte ve toprağın kimyevi kirletilmesine sebebiyet vermektedir. ${ }^{1}$

Dünya Sağlık Örgütü (DSÖ) akılcı ilaç kullanımını "bireylerin klinik bulgularına ve bireysel özelliklerine göre uygun ilacın, uygun süre ve dozda, en düşük maliyetle ve kolayca sağlanabilmesi” olarak tanımlanmıştır. ${ }^{3}$ Akılcı ilaç kullanımı (AİK) hastaya doğru tanının konmasından başlayıp, hastanın özelliklerine göre en etkin tedavinin seçilmesi, tedavinin başlanması, sonuçların izlenmesi ve değerlendirmesini içeren bütüncül bir yaklaşımdır. ${ }^{4}$ Akılcı olmayan ilaç kullanımı hastaların ilaçtan yeterince fayda görmemelerine sebep olmakta ve ekonomik açıdan bakıldığında ise ülke ekonomisine büyük bir yük getirmektedir. Türkiye'de 2002 yılında tüketilen ilaç kutu sayısı 699 milyon iken \%146 artarak 2011 yılında 1 milyar 721 milyon kutuya ulaşmıştır. Aynı dönemde kamu ilaç harcaması 2011 fiyatlarıla 13 milyar 430 milyon Türk Lirasından
\%18 artarak 15 milyar 865 milyon Türk Lirasına yükselmiştir. ${ }^{5}$ Ülkemizde tedavi gruplarına göre ilaç tüketimini $\% 11,0$ antibiyotikler ve $\% 11,0$ antiromatizmal ilaçlar, $\% 8,7$ kardiyovasküler, \%7,4 soğuk algınlığı ve öksürük ilaçlar1, \%7,1 analjezikler ve $\% 6,7$ sindirim sistemine yönelik ilaçlar oluşturmaktadır. ${ }^{6}$ Akılcı olmayan ilaç kullanımı az gelişmiş ve gelişmekte olan ülkelerde daha fazla olmakla birlikte, tüm ülkelerin önemli bir sağlık sorunu olarak karşımıza çıkmakta ve aynı zamanda akılcı olmayan ilaç kullanımı, düzeltilmesi zor bir alışkanlık olmaktadır.?

İlaçlar kullanım süresi geçtiğinde veya kullanım dışı kaldığında vücudumuzda ne gibi etkilere yol açacağı bilinmemektedir. Bu etkiler, ilacın hangi koşullarda saklandığına, son kullanım süresinin ne kadar aşıldığına ve ne tür ilaçlarla aynı ortamda bulunduğu gibi faktörle ilişkilidir. İlaç kullanılmadan veya tamamen tüketilmeden kişinin iyileşmesi, terapötik etkisi olmadığı için veya yan etkilerinden dolayı kullanımının hasta veya doktora bağlı olarak bırakılması, hastanın ilacı kullanmayı reddetmesi, ambalajın hastanın ihtiyacından fazla ilaç içermesi, tamamen tüketilmeden önce ilacın kullanım süresinin dolması gibi nedenlerle, kullanıcılar ilacı kullanmayı keserek ilacı atık durumuna getirebilir. İlaç üretiminin her yıl giderek büyük hacimlere ulaşması, beraberinde kullanım dışı kalmış ilaçların miktarını da artırmaktadır. ${ }^{8}$ Hastaların ilaçların kullanımıyla ilgili doğru bilgiye sahip olmamaları, hastanın tedavisinin yarım kalmasına ve kullanılan ilaçların atık ilaç durumuna düşerek evlerdeki atık ilaç sayısının artmasına sebep olmaktadır. Özellikle çocuklu ailelerde bulunan ilaçlar potansiyel zehirlenmelere sebebiyet verebilir. $\mathrm{Bu}$ ailelerde miadını doldurmadığı halde riskli olan ilaçlar, atık ilaç olmasıyla daha da riskli hale gelmektedir. ${ }^{1}$ Amerika Birleşik Devletleri'nde ilaçların teminatsız depolama veya bertaraf edilmesinden dolayı en yaygın kaza ilaç zehirlenmeleridir. ABD'de, her yıl beş yaşın altında çok sayıda çocuk kasıtsız zehirlenme sonucu ölmektedir. ${ }^{9}$ Evlerde bulunan kullanım dışı kalmış ilaç zehirlenmeleri ile ilgili araştırmalarda en çok ölümün çocukluk çağında olduğu belirtilmektedir. ${ }^{10-14}$ Evlerde bulunan kullanım dışı kalmış 
ilaçların artması ve bilinçsizce bertaraf edilmesi çevre güvenliği açısından da tehlikelidir. Bazı ilaçlar, güvenlik ve etkinlik değerlerinin altında kullanılan dozu, bozulma ürünleri ve farklı biyolojik aktivite özelliklerinden dolayı insanlar, hayvanlar kısacası ekosistem üzerinde beklenmedik etkilere sebep olabilir. ${ }^{15,16} 2002$ yılında The United States Geological Survey (USGS), ilaçların ve diğer kişisel bakım ürünlerinin genellikle ülkenin yüzey sularında bulunduğunu göstermiştir. USGS çalışmada, reçetesiz satılan ilaçların atıklarının akarsularda\% 80'den fazla olduğunu; reçetesiz antibiyotiklerin miktarının ise bu değerin yaklaşık yarısı kadar olduğunu tespit etmiştir. ${ }^{8}$

Yüzey sularında yüksek düzeyde antibiyotik bulunması, antibiyotiğe dayanıklı bakterilerin oluşmasına ve su bitkilerinde büyümenin azalmasına sebep olmaktadır. ${ }^{17-18}$ $\mathrm{Bu}$ çalışmanın amacı Adana Çukurova ilçesinde yaşayan hane halkının atık ilaç konusunda bilgi, tutum ve davranışlarını belirlemektir.

\section{GEREÇ ve YÖNTEMLER}

Çalışmamız tanımlayıcı tiptedir. Adana Çukurova nüfusu evrenimizi oluşturmaktadır. 2017 yılı Adana Çukurova ilçesinin nüfusu 364 bin olup epiinfo programı kullanılarak \%95 güven aralığı, \%5 hata payı ile çalışmaya 384 kişi dahil edilmesi planlanmıștır. Sistematik örneklemle haneler seçil ve her haneden tek bir kişiyle görüşülerek yüz yüze anket yapılmıştır. Anket uygulanmadan önce katılımcıların yazılı onamları alınmıştır. Anketler 2019 Şubat ve Mart aylarında ailenin çalışan ve okuyan bireylerine de ulaşabilmek amaciyla hafta içi 2, hafta sonu 2 gün gidilerek tamamlanmıştır. Anket sosyodemografik veriler ve atık ilaç depolanması ve bertarafı ile ilgili 18 sorudan oluşmaktadır. İlaç kutusunun yerinin uygunluk kriteri olarak ilacın prospektüsünde ki uygunluk şartlarını sağlama ve ayrıca küçük çocuğu olan evlerde ilaç dolabının çocuğun ulaşamayacağı yerde olması uygun olarak kabul edilmiştir. Atık ilaç tanımı; tedavi amacıyla alınmış ve bir miktarı kullanıldıktan sonra geri kalanı evde kullanılmadan kalan ilaç olarak belirtilmiştir. Veriler Statistical Packag for the
Social Sciences (SPSS) sürüm 25 paket programına girilmiştir. $\mathrm{P}<0,05$ anlamlı kabul edilmiştir. Analizlerde tanımlayıcı istatiksel analizler (frekans, yüzde dağılım, standart sapma) ve analitik istatistiksel analizler (bağımsız gruplarda t testi) kullanılmıştır. Çalışma yapılmadan önce T.C. Çukurova Üniversitesi Tip Fakültesi Girişimsel Olmayan Araştırmalar Etik Kurulundan izin alınmıştır.(Etik kurul tarih: 1 Şubat 2019,karar no:12)

\section{BULGULAR}

Çalışmaya katılanların \%69'u (265) kadındı ve çalışmaya katılanların yaş ortalaması 41,55 yıl $\pm 9,82^{`}$ ydi. (min. 19,max.65) Araştırmaya katılanların \%68,3’ü (262) lise ve üstü bir okula gitmişti ve \%43,2'si(166) gelir getiren bir işte çalışıyordu. Ailelerin \%30,5 (117) 'i 0-6 yaş aralığında küçük çocuğa sahipti. Katılımcıların \%39,82nin (153) evinde kronik hastalığı olan birey vardı. Katılımcıların \%89,6's1nın (344) sosyal güvencesi vardı. (Tablo1)

İlaçların \%26,6’sı (102) uygunsuz yerlerde muhafaza edilmekteydi. Katılımcıların \%69,8’i (268) ilacı kullanmadan önce son kullanma tarihini kontrol ediyordu. Katılımcıların\%93,5’i (359) kullanmadıkları ilaçlarını kutusuyla beraber çöpe atıyordu. Ailesinde 0-6 yaş grubunda çocuğu olan katılımcılardan \%7,3'nün (28) çocuğun ilaca ulaşmasıyla zehirlenme vakası yaşanmıştı(tablo2)

Katılımcılar aynı zamanda evlerinde ki kızartma yağlarını \%44,3’ü (170) lavaboya dökerek ,\%45,6’sı çöpe dökerek ve \%10,2'si (39) marketlerdeki geri dönüşüm variline götürerek bertaraf etmekteydi. Atık pilleri ise $\% 88,5$ 'i (340) çöpe atma ,\%11,5'i marketlerdeki atık pil kutusuna götürerek bertaraf etmekteydi.(Tablo3)

Evlerde kullanım dışı kalmış ilaç sayısı ortalama 4,26/hane 'ydi. Kullanım dışı kalmaların en sık nedeni son kullanma tarihinin geçmiş olması ve hastanın ilacı beğenmeyerek kullanmaya devam etmek istememesi idi. İlaç çeşidi olarak ise sırayla en sık analjezik, antibiyotik ve antihistaminik ilaçlar gelmekteydi.(Tablo 4) 
Katılımcılarda sağlık güvencesi olanlarda evde bulunan kullanım dışı ilaç sayısı daha fazlaydı ve bu istatiksel olarak anlamlıydı. Evde kronik hasta birey bulunan ailelerde kullanım dışı atık ilaç sayısı açısından fark bulunmadı. İlaç kutusu yeri ve ilacı kullanmadan önce son kullanma tarihini kontrol etme açısından evde bulunan kullanım dışı atık ilaç sayısı ile ilişki bulunamadı. Daha önce ilaçlara bağlı çocuklarında zehirlenme meydana gelmiş ailelerde evde bulunan kullanım dışı atık ilaç sayısı daha fazlaydı.

(Tablo 5)

\begin{tabular}{|c|c|c|c|}
\hline \multicolumn{4}{|c|}{$\begin{array}{l}\text { Tablo 1. Adana Çukurova İlçesinde Yaşayan Hanehalkın- } \\
\text { da Çalışmamıza Katılanların Sosyodemografik Özellikleri } \\
\text { (n:384) }\end{array}$} \\
\hline \multicolumn{2}{|c|}{ Özellikler } & $\mathrm{N}$ & $\%$ \\
\hline \multirow{3}{*}{ Yaş (yıl) } & 29 yaş ve altı & 51 & 13,3 \\
\hline & 30-59 yaş arası & 313 & 81,5 \\
\hline & 60 yaş ve üstü & 20 & 5,2 \\
\hline \multirow{2}{*}{ Cinsiyet } & Kadın & 265 & 69,0 \\
\hline & Erkek & 119 & 31,0 \\
\hline \multirow{4}{*}{$\begin{array}{l}\text { Eğitim } \\
\text { durumu }\end{array}$} & İlkokul ve altı & 43 & 11,2 \\
\hline & Ortaokul & 79 & 20,6 \\
\hline & Lise & 193 & 50,3 \\
\hline & Üniversite & 69 & 18,0 \\
\hline \multirow{2}{*}{$\begin{array}{l}\text { Çalışma } \\
\text { durumu }\end{array}$} & Çalışmıyor & 218 & 56,8 \\
\hline & & 166 & 43,2 \\
\hline \multirow{3}{*}{$\begin{array}{l}\text { Sağlik } \\
\text { Güvencesi }\end{array}$} & SGK & 290 & 75,5 \\
\hline & Yeşilkart & 54 & 14,1 \\
\hline & Yok & 40 & 10,4 \\
\hline \multirow{5}{*}{$\begin{array}{l}\text { Ailede } \\
\text { Yaşayan Kişi } \\
\text { Sayısı }\end{array}$} & 2 & 25 & 6,5 \\
\hline & 3 & 81 & 21,1 \\
\hline & 4 & 131 & 34,1 \\
\hline & 5 & 130 & 33,9 \\
\hline & 6 & 17 & 4,4 \\
\hline \multirow{2}{*}{ 0-6 Yaş Çocuk } & Var & 117 & 30,5 \\
\hline & Yok & 267 & 69,5 \\
\hline \multirow{2}{*}{$\begin{array}{l}\text { Evde Kronik } \\
\text { Hastalığı } \\
\text { Olan Birey }\end{array}$} & Var & 153 & 39,8 \\
\hline & Yok & 231 & 60,2 \\
\hline
\end{tabular}

Tablo 2. Adana Çukurova İlçesinde Yaşayan Hanehalkında Çalışmamıza Katılanların Evlerindeki İlaç Kutusu Yerleri, İlacı Kullanmadan Önce Son Kullanma Tarihini Kontrol Etme Durumları, İlaçları Bertaraf Etme Yöntemleri ve İlaçla Çocuklarında Zehirlenme Varlığı Durumları (n:384)

\begin{tabular}{|l|c|c|c|}
\hline \multicolumn{2}{|l|}{ Özellikler } & $\mathrm{N}$ & $\%$ \\
\hline \multirow{2}{*}{$\begin{array}{l}\text { İlaç Kutusu } \\
\text { Yeri }\end{array}$} & Uygun & 282 & 73,4 \\
\cline { 2 - 4 } & Uygunsuz & 102 & 26,6 \\
\hline $\begin{array}{l}\text { İlaç Kullan- } \\
\text { madan Önce } \\
\begin{array}{l}\text { Son Kullanım } \\
\text { Tarihini Kon- } \\
\text { trol Etme }\end{array}\end{array}$ & Evet & 268 & 69,8 \\
\cline { 2 - 4 } $\begin{array}{l}\text { İlaç Bertaraf } \\
\text { Etme Yöntemi }\end{array}$ & Kuyır & 116 & 30,2 \\
\cline { 2 - 4 } $\begin{array}{l}\text { İlaçla Çocuk } \\
\text { Zehirlenmesi }\end{array}$ & Tuvalete Atma & 25 & 6,5 \\
\cline { 2 - 4 } & Evet & 28 & 7,3 \\
\hline
\end{tabular}

Tablo 3. Adana Çukurova İlçesinde Yaşayan Hanehalkında Çalışmamıza Katılanların Yağ ve Pilleri Bertaraf Etme Yöntemi(n:384)

\begin{tabular}{|l|c|c|c|}
\hline \multicolumn{2}{|l|}{ Özellikler } & $\mathrm{N}$ & $\%$ \\
\hline \multirow{3}{*}{$\begin{array}{l}\text { Yağı Bertaraf } \\
\text { Etme }\end{array}$} & Lavaboya Dökme & 170 & 44,3 \\
\cline { 2 - 4 } & Çöpe Dökme & 175 & 45,6 \\
\cline { 2 - 4 } & Marketlere Götürme & 39 & 10,2 \\
\hline \multirow{2}{*}{$\begin{array}{l}\text { Pilleri Ber- } \\
\text { taraf Etme }\end{array}$} & Çöpe Atma & 340 & 88,5 \\
\cline { 2 - 4 } & Markete Götürme & 44 & 11,5 \\
\hline
\end{tabular}




\begin{tabular}{|c|c|c|c|}
\hline \multicolumn{4}{|c|}{$\begin{array}{l}\text { Tablo 4. Adana Çukurova İlçesinde Yaşayan Hanehalkında } \\
\text { Çalışmamıza Katılanların Evlerinde Bulunan Kullanım } \\
\text { Dışı Kalmış İlaçların Türü Ve Neden Kullanım Dıșı Kaldığı } \\
\text { (N:1638) }\end{array}$} \\
\hline \multicolumn{2}{|l|}{ Özellikler } & $\mathrm{N}$ & $\%$ \\
\hline \multirow{11}{*}{$\begin{array}{l}\text { Kullanım dışı } \\
\text { kalmış ilacın } \\
\text { türü }\end{array}$} & Analjezik & 357 & 21,79 \\
\hline & Antibiyotik & 307 & 18,74 \\
\hline & Solunum Sistemi İlacı & 51 & 3,11 \\
\hline & $\begin{array}{l}\text { Gastrointestinal Sistem } \\
\text { İlacı }\end{array}$ & 243 & 14,83 \\
\hline & Dermatolojik İlaç & 98 & 5,98 \\
\hline & Kardiyovasküler İlaç & 149 & 9,09 \\
\hline & Antihistaminik & 267 & 16,30 \\
\hline & Oftalmik preparat & 17 & 1,03 \\
\hline & Antidiyebetik & 98 & 5,98 \\
\hline & Antidepresan & 24 & 1,46 \\
\hline & $\begin{array}{l}\text { Merkezi Sinir Sistemi } \\
\text { İlacı }\end{array}$ & 27 & 1,64 \\
\hline \multirow{5}{*}{$\begin{array}{l}\text { Neden } \\
\text { kullanım dışı }\end{array}$} & $\begin{array}{c}\text { Son Kullanım Tarihi } \\
\text { Geçmiş }\end{array}$ & 908 & 55,43 \\
\hline & Hasta İyileşmiş & 196 & 11,96 \\
\hline & Doktor İlacı Değiștirmiş & 36 & 2,19 \\
\hline & $\begin{array}{l}\text { Hasta İlaca Devam } \\
\text { Etmek İstememiş }\end{array}$ & 430 & 26,25 \\
\hline & $\begin{array}{c}\text { İlaca Karşı Alerjik Reak- } \\
\text { siyon Gelişmiş }\end{array}$ & 68 & 4,15 \\
\hline
\end{tabular}

Tablo 5. Adana Çukurova İlçesinde Yaşayan Hanehalkında Çalışmamıza Katılanların Evlerindeki Atık İlaç Sayıları ve Bazı Değişkenlerle İlişkisi(N:384)

\begin{tabular}{|c|c|c|c|c|}
\hline \multicolumn{2}{|l|}{ Değişkenler } & $\begin{array}{c}\text { Evde ki } \\
\text { Atık İlaç } \\
\text { Sayıları }\end{array}$ & $\mathrm{t}$ & $\mathrm{P}$ \\
\hline \multirow{2}{*}{$\begin{array}{l}\text { Sağllk } \\
\text { Güvencesi }\end{array}$} & Var & $436+267$ & \multirow{2}{*}{3,044} & \multirow{2}{*}{0,003} \\
\hline & Yok & $3,42 \pm 1,72$ & & \\
\hline \multirow{2}{*}{$\begin{array}{l}\text { Evde Kronik } \\
\text { Hastalığ } 1\end{array}$} & Var & $4,12 \pm 2,80$ & \multirow{2}{*}{,- 848} & \multirow{2}{*}{0,397} \\
\hline & Yok & $4,35 \pm 2,55$ & & \\
\hline \multirow{2}{*}{ İlaç Kutusu Yeri } & Uygun & $4,18 \pm 2,71$ & \multirow{2}{*}{$-1,153$} & \multirow{2}{*}{0,250} \\
\hline & Uygunsuz & $4,50 \pm 2,26$ & & \\
\hline \multirow{2}{*}{$\begin{array}{l}\text { Kullanmadan } \\
\text { SKT Kontrol }^{*}\end{array}$} & Ediyorum & $4,37 \pm 2,65$ & \multirow{2}{*}{1,272} & \multirow{2}{*}{0,204} \\
\hline & Etmiyorum & $4,00 \pm 2,47$ & & \\
\hline \multirow{2}{*}{$\begin{array}{l}\text { İlaçla Çocuk } \\
\text { Zehirlenmesi }\end{array}$} & Evet & $5,89 \pm 2,88$ & \multirow{2}{*}{3,473} & \multirow{2}{*}{0,001} \\
\hline & Hayır & $4,13 \pm 2,54$ & & \\
\hline
\end{tabular}

\section{TARTIŞMA}

Belçika'da yapılan bir çalışmada, araştırmaya dâhil edilen evlerin hepsinde ilaç bulunduğu saptanmıştır. ${ }^{19}$ Ankara’daki bir çalışmada evde artık ilaç bulunma düzeyi $\% 44,8$ olarak bulunmuştur. ${ }^{20}$ Bizim çalışmamızda evdeki atık ilaç sayısı ortalama 4,26/hane 'ydi. Toplum genelinde de aile bazında düşünüldüğünde de çok yüksek bir rakamdır. Gerek bu ilaçların çocuklarda zehirlenmelere yol açabilmesi gerekse büyüklerde intihar amaçı kullanılabilmesi açısından gerekse de israf açısından bakıldığında ivedilikle bu sorun çözülmeli, önleyici tedbirler alınmalıdır.

Ankara'daki bir çalışmada katılımcıların \%28,3'ü ilaçların son kullanma tarihlerine bakmadıklarını söylemişlerdir. ${ }^{20}$ Belçika'daki bir çalışmada, evlerde mevcut ilaçların yaklaşık üçte birinin uygunsuz şartlarda korunduğu belirlenmiştir. ${ }^{19}$ Bizim çalışmamızda da ilaçların \%26,6'sı uygunsuz yerlerde muhafaza edilmekteydi ve sadece katılımcıların \%69,8'i ilacı kullanmadan önce son kullanma tarihini kontrol ediyordu. Yüzdeler literatürle uyumlu olsa da ilaçlar uygunsuz yerlerde muhafaza edildiğinde veya son kullanma tarihleri geçtiğinde etkisini kaybedip mevcut hastalığın tedavisiz kalmasına sebep olabileceği gibi beklenmeyen etkilere bağlı başka rahatsızlıklarının ortaya çıkmasına da sebebiyet verebilir. Amerika Birleşik Devletleri'nde yapılan bir çalışmaya göre her 7 dakikada bir zehirlenme şüphesiyle acil servislere bir pediatrik hasta getirilmektedir. Bu hastaların da 78.000'i 5 yaşından küçük çocuklardan oluşmaktadır. Bu çocukların zehirlenmelerine neden olan etkenler ise; evlerde bulunan ilaçlar ve diğer amaçlar (temizlik vs.) için kullanılan maddelerdir. Ülkemizdeki ilaçlardan kaynaklanan zehirlenme olgularının varlığı ve sıklığını sorgulayan pek çok çalışma mevcuttur. ${ }^{21}$ Örneğin; bir çalışmada, Türkiye’nin değişik bölgelerindeki 38 sağlık kuruluşundan bildirilen 5077 çocuk zehirlenme olgusunun en sık 13 ay - 4 yaş grubunda, erkeklerde ve ilkbahar ile yaz aylarında görüldüğü belirtilmiştir. Zehirlenme nedeni olarak ilk sırada ilaçlar yer almaktadır. Bölgesel olarak yapılan bazı çalışmalarda da 13 ay - 4 yaş grubunda çocuk acil polikliniğine getirilen zehirlenme 
olgularında da ilk sırayı ilaçtan kaynaklanan olgular oluşturmaktadır. ${ }^{22-25}$ Zehirlenmeler her yaşta görülebilmekle birlikte, önemli bir miktarı 5 yaş altında görülmektedir. ${ }^{26-29}$ Çocuklardaki ilaç zehirlenmelerinin önlenmesi açısından ilaçların uygun koşullarda ve erişemeyecekleri yerlerde saklanmaları önemlidir. Halkın bu konuda eğitime ihtiyacı vardır. ${ }^{20,30}$ Bizim çalışmamızda da katılımcıların ailesinde \%7,3'nün 0-6 yaş arası çocuğunda çocuğun ilaca ulaşmasıyla zehirlenme vakası meydana gelmiştir. Bu rakamlar çok yüksek olmasına rağmen zehirlenmelerin hepsi ölümle sonuçlanmadığı için yeterli dikkati çekmese de hepsinin aslında ölümle de sonuçlanma ihtimali olduğu düşünülürse çok büyük bir problem olduğu görülecektir.

İspanya'da 2007 yılında yapılan bir çalışmada, 227 eczane müşterisi, 8 gün içerisinde evlerinde kullanmadıkları 1176 paket ilacı geri getirmişlerdir. Bu ilaçların toplam değeri: $8.540 €$ olup bunun $6.464 €$ bedeli devlet tarafından ödenmektedir. Bu ilaçların geri getirilme nedenleri ;son kullanma tarihinin geçmesi \%28, hastanın iyileşmesi\% 25 ,hastanın ölümü \%21 ve tedavi şeklinde değişiklik yapılması $\% 12$ idi, getirilen ilaçlar ise ; gastro-intestinal sistem ve metabolizma $\% 18$, sinir sistemi $\% 18$, kardiyovasküler $\% 12$, sistemik anti-enfeksiyon $\% 7$ şeklindeydi. Türkiyede de çeşitli nedenlerle evlerde kullanılmayan ilaçlar birikmektedir. Zaman zaman kampanyalar düzenlenerek ihtiyacı olan dar gelirli insanlara bu ilaçlar dağıtılmaktadır. Benzer bir çalışma, 2008 yılında, Eskişehir'de yapılmış, 2 aylık sürede 500.000 YTL değerinde 16.000 kutu ilaç toplanmıştır. Toplanan ilaçların 5.500 kutusunun kullanılamayacak durumda oldukları belirtilmiş, diğerleri ise İl Sağlık Müdürlüğü aracılığı ile ihtiyaç sahiplerine ulaştırıldığı belirtilmiştir. İlaçların evlerde birikimi sonucu çöpe atılmalarının yanı sıra diğer nedenler ile de toplu halde çevreye atıldığ 1 olaylar mevcuttur. ${ }^{31}$ Bu bağlamda, Eylül 2007 yılında Muğla’nın Ortaca ilçesinde kapanan bir eczanedeki 1.500 kutu ilacın cadde üzerindeki çöp bidonlarına atıldığı, yine benzer şekilde Mayıs 2008 yılında Muğla’nın Milas ilçesinde 350 kutu ilacın sokağa atıldığı belirtilmiştir. ${ }^{32}$ Ankara'daki bir çalışmada katılımcıların \%28,6’sı doktorun önerdiği ilaçları kullanılması gereken süreden önce kestiğini belirtmiş.20 Yapıcı ve arkadaşlarının (2011) yaptıkları bir çalışmada araştırmaya katılanların \% 26'sının doktor tavsiyesi olmadan ilaç kullandıkları, \% 15'inin evlerinde bulunan ilaçları kullandıkları, \%43.7'sinin ise ilacları kullanılması gereken süreden önce bıraktıkları tespit etmişlerdir. ${ }^{33}$ Özçelikayın yaptığ 1 bir çalışmada ise doktora başvurmadan ilaç kullanım oranı \%75,5 olduğu bu ilaçların \% 54'luk kısmını ağrıkesiciler, \%8'ini antibiyotikler, \%5'ini ise soğuk algınlığı ilaçları oluşturduğu tespit edilmiştir. ${ }^{34}$ Şendir ve arkadaşlarının ile Pınar ve arkadaşlarının yaptığı çalışmada; hastaların iyileştiğini düşündüklerinde, kendini daha iyi hissettiklerinde ve daha fazla ilaç kullanmayı istemedikleri durumlarda doktorun önerdiği süreden önce ilaç kullanımını bıraktıkları görülmüştür ve bu durum araştırma sonuçları ile benzerlik göstermektedir. ${ }^{35,36}$ Bizim çalışmamızda ise kullanım dışı kalmaların en sık nedeni son kullanma tarihinin geçmiş olması ve hastanın ilacı beğenmeyerek kullanmaya devam etmek istememesiydi. İlaç çeşidi olarak ise sırayla en sık analjezik, antibiyotik ve antihistaminik ilaçlar gelmekteydi. Evlerdeki kullanım dışı ilaçlar arasında antibiyotiklerin analjeziklerden sonra gelme sebebi ülkemizde kısa süre öncesine kadar reçetesiz antibiyotik alınabilmesi olabilir. İlerde yapılacak benzer çalışmalar ile reçetesiz antibiyotik alınmamasının evlerde ki atık antibiyotik ilaç sayısına etkisi araştırılabilir. Ülkemizde Avrupa Birliği ülkelerine göre atık ilaçlar içinde antibiyotiklerin daha çok pay kaplamasının bir başka sebebi de Avrupa Birliği ülkelerinde yürürlükte olan ilaç uygulamalarına göre hastalara tedavisini bitirecek sayıda antibiyotik verilmesi ve devletin bu sınırın üstündeki antibiyotik alımları için herhangi bir ödeme yapmamasıdır. ${ }^{37,38}$

Çalışmamızda katılımcıların kızartma yağlarını \%10,2'si marketlerdeki geri dönüşüm variline götürerek, atık pilleri ise $\% 11,5$ 'i marketlerdeki atık pil kutusuna götürerek bertaraf etmekteydi. Fakat atık ilaçla ilgili herhangi bir geri dönüşüm şansı olmaması ilaçlarını evlerde tutmak istemeyen katılımcıların bu konuda çaresiz kalmasına neden olmuş olabilir. 
Evde bulunan kullanım dışı atık ilaç sayısı sağlık güvencesi bulunan katılımcılarda daha yüksekti bu kullanıcıların ücret ödemeden ilaç aldıklarında ihtiyacı olmayan ilaçları yazdırmak istemesinden kaynaklanabilir. Evde kronik hasta birey olan evlerde atık ilaç açısından diğer evlerle arasında fark bulunmamıştır. Bunun sebebi evde kronik hasta olan bulunan evlere daha çok ilaç girse bile hastalarının bu ilaçların atık duruma düşürmeden kullandıkları ve tükettikleri için olabilir. İlaç kutusu yeri uygunsuz olan evlerde uygun olmayan şartlardan dolayı ilaçların unutulup yada bozularak kullanım dışı kalacağını öngörmüştük fakat çalışmamızda bu açıdan anlamlı bir fark bulunmadı. Bunun sebebi evde ki kullanım dışı ilaç fazlalığının ilaçların yanlış yerlerde saklanarak özelliğinin kaybetmesinden değil, eve giren ilaç sayısının lüzumsuz olmasından kaynaklanıyor olabilir. Daha önce çocuklarında zehirlenme meydana geldiği halde halen evlerinde ilaçların uygunsuz yere bırakanlarda atık ilaç sayısı daha fazlaydı.

\section{SONUÇ}

Çalışmaya katılan evlerde atık ilaç sayısı çok yüksekti. Atık ilaç sayısını düşürmek için sağlık personellerine ve bireylere çok iş düşmektedir. Öncelikli hedef akılcı ilaç kullanımı teşvik edilip gereksiz yazılan ilaçların önüne geçilmesi gerekmektedir. Antibiyotiklerin reçetesiz alınmaması bu konuda alınmış güzel bir karar olup uzun vadede evlerdeki atık antibiyotik sayısını düşüreceği beklenmektedir. Yazılan ilaçlar hastanın tam kullanacağı kadar yazılıp evlerde birikmenin önüne geçilmelidir. Çalışmamızda evlerde bulunan atık yağ ve pillerini atık kutularna sürekli atan katılımcılar vardı fakat atık ilaçlarla ilgili herhangi bir uygulama olmaması bu kişilerin elini kolunu bağlamaktadır. Geri dönüşümü olmayan ilaçlar devlet bütçesine zarar verdiği gibi çocuk zehirlenmelerine de neden olmaktadır. Evlerde ki kullanım dışı kalmış ilaçların geri dönüşümü ile ilgili düzenlemeler ivedilikle yapılmalı ve başta gereksiz yazılmaması daha sonrasında ise geri dönüşümü sağlanmalıdır. 
Sakarya Tip Dergisi 2019;9(3):398-405

ÇOT ve Ark., Hane Halkının Atık İlaç Konusunda Bilgi ve Davranışları

\section{Kaynaklar}

1. Özcan V.,Evsel İlaç Atıkları Çevre Ve İnsan Sağlı̆̆ı,TEB Haberler Ocak -Șubat 2009 sayı:1

2. Arslankaya E., Istanbul Metropolitanında Evsel Zararl Atık Potansiyelinin Araştırılması, Ekoloji Çevre Dergisi, Temmuz-Agustos-Eylül 1995 Sayl: 16

3. WHO. The Rational use of drugs: report of the conference of experts, Nairobi, 25-29 November 1985: World Health Organization; 1987.

4. WHO. Guide to good prescribing: a practical manual. 1997:7-16.

5. Sağllk Bakanlı̆̆ı. Stratejik Plan 2013-2017. Ankara. 2012:46.

6. İEİS. Türkiye İlaç Pazarı. Erișim tarihi 6.5.2019 2019. p. Erișim adresi, http://www.ieis.org. tr/ieis/tr/ indicators/33/turkiye-ilac-pazari.

7. Acar A, Yeğenoğlu S. Akılcı ilaç kullanımı açısından farmakoekonomi ve hastane formülleri. Ankara Eczacilk Fakültesi Dergisi 2005;34(3):207-18.

8. Boxall, Alistair B. The environmental side effects of medication. European Molecular Biology Organization Reports 2004; 5: 1110-6.

9. United States Consumer Product Safety Commission.2005 Annual report of all-terrain vecihle (ATV)-related death and injuries. PDF Dokümani. [http://www.cpsc. gov/PageFiles/87678/atv2005.pdf; Erișim Tarihi: 26 Ağustos 2013].

10. National Suicide Prevention Strategy for England. PDF Dokümant [http://www.nmhdu. org.uk/silo/files/ national-suicide-prevention-strategy-for-england.pdf; Erişim Tarihi: 26 Ağustos 2013].

11. De Bolle L, Mehuys E, Adriaens E, Remon JP, Van Bortel L, Christiaens T. Home medication cabinets and selfmedication:a source of potential health threats? Ann Pharmacother 2008; 42: $572-9$.

12. Ruhoy IS, Daughton CG. Beyond the medicine cabinet:An analysis of where and why medications accumulate.Environ Int 2008; 34: 1157-69.

13. Herring ME, Shah SK, Shah SK, Gupta AK. Current Regulationsand Modest Proposals Regarding Disposal of Unused Opioids and Other Controlled Substances. J Am Osteopath Assoc 2008; 108: 338-43.

14. İlkkurş̧unlu Ș. İlaç atık ve bertaraf projesi. [www.atikilac.com/Evsel_Atik.pps.; Erișim Tarihi: 26 Ağustos 2013].

15. Șahan S, Battal D, Șahin NÖ. Çevre ve insan sağlı̆̆ıyönünden ilaç atıklarının önemi. Marmara Pharm J 2012;16: 82-90.

16. Bound JP, Voulvoulis N. Household disposal of pharmaceuticals as a pathway for aquatic contamination in the United Kingdom. Environ Health Perspect 2005; 113:1705-11.

17. Daughton CG, Ternes TA. Pharmaceuticals and personalcare products in the environment: Agents of subtle change? Environ Health Perspect 1999; 107: 907-38.

18. Coma A, Modamio P, Lastra CF, Bouvy ML, Mariño EL. Returned medicines in community pharmacies of Barcelona. Pharm World Sci 2008; 30: 272-7.

19. De Bolle L, Mehuys E, Adriaens E, Remon JP,Van Bortel L, Christiaens T. Home medication cabinets and self-medication: a source of potential health threats? Ann Pharmacother.2008; 42(4):572-9.

20. Özkan S, Özbay OD, Aksakal FN, İlhan MN, Aycan S. Bir Üniversite Hastanesine Bașvu- ran Hastaların Hasta Olduklarındaki Tutumları Ve İlaç Kullanım Alışkanlıkları. TAF Prev Med Bull 2005;4(5): 223-237.

21. Aydınoğlu H, Aygün AD, Güngör S, Turgut M, DoğanY. Firat Üniversitesi Tip Fakültesỉ de izlenen 176 çocuk zehirlenme olgusunun değerlendirilmesi. Türk Pediatri Arşivi 2000 35:245-248.

22. Aji DY, İlter Ö. Türkiye’de Çocuk Zehirlenmeleri. Türk Pediatri Arșivi 1998; 33:154-158

23. Aji DY, Keskin S, İlter Ö. İ.Ü. Cerrahpaşa Tip fakültesi çocuk sağllğı ve hastalıları anabilim dal, acil birimince izlenen zehirlenmelerin değerlendirilmesi. Türk Pediatri Arșivi 1998; 33:148-153.

24. Aji DY. Çocuklarda akut zehirlenmeler. IUU Cerrahpaşa Tip Fakültesi Sürekli Tip Eğitimi Etkinlikleri Pediatrik Aciller Sempozyum Dizisi 2007; 57:147-161.

25. Akbay-Öntürk Y, Uçar B. Eskișehir bölgesinde çocuklukçağı zehirlenmelerinin retrospektif değerlendirilmesi. Çocuk Să̆ Hast Der 2003; 46:103-113.

26. Çetin NG, Beydilli $H$, Tomruk Ö. Acil servise başvuran intoksikasyon olgularinin geriye dönük analizi. S.D.Ü. Tip Fak. Derg 2004; 11(4): 7-9.

27. Akar T, Derinöz O, Demirel B. İlaç zehirlenmeleri ve hastane maliyetleri. Türk Ped Arş 2007; 42: 103-6.

28. Penbegül ML. İlaç Zehirlenmesi Olan Çocuk Olgularda Demografik Özellikler Ve Ailesel Etkenlerin Değerlendirilmesi. Uzmanlık Tezi. İstanbul. T.C.Sağlık Bakanlı̆̆ı Haydarpașa Numune Ĕ̆itim ve Araștırma Hastanesi ÇocukKliniği, 2006.

29. Biçer S, Sezer S, Cetindağ F, Kesikminare M, Tombulca N, Aydoğan G ve ark. Cocuk Acil Kliniği 2005 Yll Akut Zehirlenme Olgularının Değerlendirilmesi. Marmara Medical Journal 2007; 20(1); 12-20.

30. Uskun E, Başar Uskun S, Öztürk M, Kişioğlu AN. Sağlık Ocağına Başvuru Öncesi Illaç Kullanımi. Sürekli Tip Eğitimi Dergisi 2004; 13(12): 451- 454.

31.http://www.nethabercilik.com/haber/eskisehir_de_ilac_toplama_kampanyasi.htm.(Erişim tarihi:15.06.2011)

32. http://www.internethaber.com/news_detail. php?id=105214. (Erisim Tarihi: 15.06.2011).

33. 33. Yapıcı G, Balıkçı S, Uğur Ö. Birinci basamak sağllk kuruluşuna başvuranların ilaç kullanımı konusundaki tutum ve davranıșları. Dicle Tip Dergisi 2011;38(4):458-65.

34. Özçelikay G. Akılıı İlaç Kullanımı Üzerinde Bir Pilot Çalışma. Ankara Ecz Fak Der. 2001;30(2):9-18.

35. Pınar N, Karataş Y, Bozdemir N, Ünal İ. Adana İlindeki İnsanların İlaç Kullanım Alı̧̧kanlikları. TAF Preventive Medicine Bulletin 2013;12(6):639-50.

36. Şendir M, Çelik Z, Güzel E, Büyükyılmaz F. Aile sağlı̆̆ı merkezlerine başvuran bireylerde akılcı ilaç kullanım alıskanlıklarının belirlenmesi. TAF Preventive Medicine Bulletin. 2015;14(1).

37. Proper disposal of expired or unwanted drugs. Pharmacist's Letter / Prescriber's Letter 2007; 23: Detail-Document\#230401. [Erișim Tarihi: 06.05.2019]

38. Witte W. Medical Consequences of Antibiotic Use in Agriculture. Science 1998; 279: 996-7. 